\title{
PEMBAHARUAN PENDIDIKAN ISLAM DI SEKOLAH DASAR MENUJU MASYARAKAT MADANI
}

\section{Jenuri}

\section{Abstrak}

asyarakat madani merupakan suatu ujud masyarakat yang memiliki kemandirian aktivitas dengan ciri: universalitas, supermasi, keabadian, pemerataan kekuatan, kebaikan dari dan untuk bersama, meraih kebajikan umum, piranti eksternal, bukan berinteraksi pada keuntungan, dan kesempatan yang sama dan merata kepada setiap warganya. ciri masyarakat ini merupakan masyarakat yang ideal dalam kehidupan. Untuk Pemerintah pada era reformasi ini, akan mengarakan semua potensi bangsa berupa pendidikan, ekonomi, politik, hukum, sosial budaya, militer, kerah masyarakat madani yang dicita-citakan.

Sejalan dengan konsep tersebut, agar dasar pendidikan Islam relevan dengan kepentingan umat Islam dan relevan dengan disain masyarakat madani, penerapan konsep dasar filsafat dan teori pendidikan harus memperhatikan konteks suprasistem bagi kepentingan komunitas "masyarakat madani" yang dicita-citakan bangsa ini.

Kata Kunci: masyarakat madani; pembaharuan pendidikan Islam 


\section{PENDAHULUAN}

Akhir-akhir ini sering muncul ungkapan dari sebahagian pejabat pemerintah, politisi, cendekiawan, dan tokoh-tokoh masyarakat tentang masyarakat madani (sebagai terjemahan dari kata civil society). Tanpaknya, semua potensi bangsa Indonesia dipersiapkan dan diberdayakan untuk menuju masyarakat madani yang merupakan cita-cita dari bangsa ini. Masyarakat madani diprediski sebagai masyarakat yang berkembang sesuai dengan potensi budaya, adat istiadat, dan agama. Demikian pula, bangsa Indonesia pada era reformasi ini diarahkan untuk menuju masyarakat madani, untuk itu kehidupan manusia Indonesia akan mengalami perubahan yang fundamental yang tentu akan berbeda dengan kehidupan masayakat pada era orde baru. Kenapa, karena dalam masyarakat madani yang dicitacitakan, dikatakan akan memungkinkan "terwujudnya kemandirian masyarakat, terwujudnya nilai-nilai tertentu dalam kehidupan masyarakat, terutama keadilan, persamaan, kebebasan dan kemajemukan [pluraliseme]" , serta taqwa, jujur, dan taat hokum [Bandingkan dengan Masykuri Abdillah, 1999:4].

Konsep masyarakat madani merupakan tuntutan baru yang memerlukan berbagai torobosan di dalam berpikir, penyusunan konsep, serta tindakan-tindakan. Dengan kata lain, dalam menghadapi perubahan masyarakat dan zaman, "diperlukan suatu paradigma baru di dalam menghadapi tuntutantuntutan yang baru, demikian kata filsuf Kuhn. Karena menurut Kuhn, apabila tantangan-tantangan baru tersebut dihadapi dengan menggunakan paradigma lama, maka segala usaha yang dijalankan akan memenuhi kegagalan".

Terobosan pemikiran kembali konsep dasar pembaharuan pendidikan Islam menuju masyarakat madani sangat diperlukan, karena "pendidikan sarana terbaik yang didisain untuk menciptakan suatu generasi baru pemuda-pemudi yang tidak akan kehilangan ikatan dengan tradisi mereka sendiri tapi juga sekaligus tidak menjadi bodoh secara intelektual atau terbelakang dalam pendidikan mereka atau tidak menyadari adanya perkembangan-perkembangan disetiap cabang pengetahuan manusia [Conference Book, London, 1978:16-17]. Berdasarkan apa yang dikemukakan di atas, maka masalah yang perlu dicermati dalam pembahasan ini adalah bagaimanakah pendidikan Islam didisain menuju masyarakat madani Indonesia.

\section{KONSEP MASYARAKAT MADANI}

Istilah masyarakat Madani sebenarnya telah lama hadir di bumi, walaupun dalam wacana akademi di Indonesia belakangan mulai tersosialisasi. "Dalam bahasa Inggris ia lebih dikenal dengan sebutan Civil Society". Sebab, "masyarakat Madani", sebagai terjemahan kata civil society atau al-muftama' almadani. ....Istilah civil society pertama kali dikemukakan oleh Cicero dalam filsafat politiknya dengan istilah societies civilis, namun istilah ini mengalami perkembangan pengertian. Kalau Cicero memahaminya identik dengan negara, maka kini dipahami sebagai kemandirian aktivitas warga masyarakat madani sebagai "area tempat berbagai gerakan sosial" [seperti himpunan ketetanggaan, kelompok wanita, kelompok keagamaan, dan kelompk intelektual] serta organisasi sipil dari semua kelas [seperti ahli hukum, wartawan, serikat buruh dan usahawan] berusaha menyatakan diri mereka dalam suatu himpunan, sehingga mereka dapat mengekspresikan diri mereka sendiri dan memajukkan pelbagai kepentingan mereka. Secara ideal masyarakat madani ini tidak hanya sekedar terwujudnya kemandirian masyarakat berhadapan dengan negara, melainkan juga terwujudnya nilai-nilai tertentu dalam kehidupan masyarakat, terutama keadilan, persamaan, kebebasan dan kemajemukan [pluralisme] [Masykuri Abdillah, 1999:4]. Sedangkan menurut, Komaruddin Hidayat, dalam wacana keislaman di Indonesia, adalah Nurcholish Madjid yang menggelindingkan istilah "masyarakat madani" ini, yang spirit 
serta visinya terbakukan dalam nama yayasan Paramadinah [terdiri dari kata "para" dan "madinah", dan atau "parama" dan "dina"]. Maka, secara "semantik" artinya kira-kira ialah, sebuah agama [dina] yang excellent [paramount] yang misinya ialah untuk membangun sebuah peradaban [madani] [Kamaruddin Hidayat, 1999:267-268].

Kata madani sepintas orang mendengar asosiasinya dengan kata Madinah, memang demikian karena kata Madani berasal dari dan terjalin erat secara etimologi dan terminologi dengan Madinah yang kemudian menjadi ibukota pertama pemerintahan Muslim. Maka, "Kalangan pemikir muslim mengartikan civil society dengan cara memberi atribut keislaman madani [attributive dari kata alMadani]. Oleh karena itu, civil society dipandang dengan masyarakat madani yang pada masyarakat idial di [kota] Madinah yang dibangun oleh Nabi Muhammad SAW. Dalam masyarakat tersebut Nabi berhasil memberlakukan nilai-nilai keadilan, prinsip kesetaraan hukum, jaminan kesejahteraan bagi semua warga, serta perlindungan terhadap kelompok minoritas. Dengan begitu, kalangan pemikir Muslim menganggap masyarakat [kota] Madinah sebagai prototype masyarakat ideal produk Islam yang dapat dipersandingkan dengan masyarakat ideal dalam konsep civil society"[Thoha Hamim, 1999:4].

Menurut Komaruddin Hidayat, bagi kalangan intelektual Muslim kedua istilah [masyarakat agama dan masyarakat madani] memilki akar normatif dan kesejarahan yang sama, yaitu sebuah masyarakat yang dilandasi norma-norma keagamaan sebagaimana yang diwujudkan Muhammad SAW di Madinah, yang berarti "kota peradaban", yang semula kota itu bernama Yathrib ke Madinah difahami oleh umat Islam sebagai sebuah manifesto konseptual mengenai upaya Rasulullah Muhammad untuk mewujudkan sebuah masyarakat Madani, yang diperhadapkan dengan masyarakat Badawi dan Nomad [Kamaruddin Hidayat, 1999:267]. Untuk kondisi Indonesia sekarang, kata Madani dapat diperhadapkan dengan istilah masyarakat Modern.

Dari paparan di atas dapat dikatakan bahwa, bentuk masyarakat madani adalah suatu komunitas masyarakat yang memiliki "kemandirian aktivitas warga masyarakatnya" yang berkembang sesuai dengan potensi budaya, adat istiadat, dan agama, dengan mewujudkan dan memberlakukan nilai-nilai keadilan, prinsip kesetaraan [persamaan], penegakan hukum, jaminan kesejahteraan, kebebasan, kemajemukan [pluralisme], dan perlindungan terhadap kaum minoritas. Dengan demikian, masyarakat madani merupakan suatu masyarakat ideal yang dicita-citakan dan akan diwujudkan di bumi Indonesia, yang masyarakatnya sangat plural.

Dari uraian di atas, maka sangat perlu untuk mengetahui ciri masyarakat tersebut. Antonio Rosmini, dalam "The Philosophy of Right, Rights in Civil Society" [1996: 28-50] yang dikutip Mufid, menyebutkan pada masyarakat madani terdapat sepuluh ciri yang menjadi karakteristik masyarakat tersebut, yaitu: Universalitas, supermasi, keabadian, dan pemerataan kekuatan [prevalence of force] adalah empat ciri yang pertama. Ciri yang kelima, ditandai dengan "kebaikan dari dan untuk bersama". Ciri ini bisa terwujud jika setiap anggota masyarakat memiliki akses pemerataan dalam memanfaatkan kesempatan [the tendency to equalize the share of utility]. Keenam, jika masyarakat madani "ditujukan untuk meraih kebajikan umum" [the common good], kujuan akhir memang kebajikan publik [the public good]. Ketujuh, sebagai "perimbangan kebijakan umum", masyarakat madani juga memperhatikan kebijakan perorangan dengan cara memberikan alokasi kesempatan kepada semua anggotanya meraih kebajikan itu. Kedelapan, masyarakat madani, memerlukan "piranti eksternal" untukmewujudkan tujuannya. Piranti eksternal itu adalah masyarakat eksternal. Kesembilan, masyarakat madani bukanlah sebuah kekuatan yang berorientasi pada keuntungan [seigniorial or profit]. Masyarakat madani lebih merupakan kekuatan yang justru memberi manfaat [a beneficial power]. Kesepuluh, kendati masyarakat madani memberi kesempatan yang sama dan merata kepada setiap warganya, tak berarti bahwa ia harus seragam, sama dan sebangun serta homogin [Mufid, 1999:213].

Lebih lanjut, menurut Mufid, menyatakan bahwa masyarakat madani terdiri dari berbagai warga beraneka "warna", bakat dan potensi. Karena itulah, masyarakar madani di sebut sebagai masyarakat "multi-kuota" [a multi quota society]. Maka, secara umum sepuluh ciri tersebut sangat idial, sehingga 
mengesankan seolah tak ada masyarakat seideal itu. Kalau ada, yaitu masyarakat muslim yang langsung dipimpin oleh Nabi SAW yang relatif memenuhi syarat tersebut. Memang, masyarakat seideal masyarakat "madinah" telah diisyaratkan oleh Nabi Muhammad SAW dalam sabdanya, "tak ada satupun masyarakat di dunia ini yang sebaik masyarakat atau sebaik-baik masa adalah masaku" [ahsanul qurun qarni] - terlepas dari status sahih dan tidaknya sabda ini, ataupun siapa periwayatnya [Mufid, 1999:213214]. Diakui bahwa masyarakat Madinah yang dipimpin langsung oleh Nabi Muhammad SAW merupakan prototype masyarakat idial. Maka, prototype masyarakat madani tersebut, pada era reformasi ini, nampaknya akan upayakan untuk diwujudkan di Indonesia atau dengan kata lain akan ditiru dalam wacana masyarakat Indonesia yang sangat pluralis.

\section{PENDIDIKAN ISLAM}

Sebelum membahas tentang pengertian pendidikan Islam, terlebih dahulu membahas apa itu pendidikan? Menurut M.J. Langeveld ; "Pendidikan merupakan upaya manusia dewasa membimbing yang belum kepada kedewasaan [Kartini Kartono, 1997:11]. Ahmad D.Marimba, merumuskan pendidikan adalah bimbingan atau pimpinan secara sadar oleh sipendidik terhadap perkembangan jasmani dan rohani siterdidik menuju terbentuknya keperibadian yang utama [Ahmad D. Marimba, 1978:20]. Demikian dua pengertian pendidikan dari sekian banyak pengertian yang diketahui. Dalam Undang-Undang Sistem Pendidikan Nasional Nomor : 2 Tahun 1989, "pendidikan dirumuskan sebagai usaha sadar untuk menyiapkan peserta didik melalui kegiatan bimbingan, pengajaran dan atau latihan bagi perannya di masa yang akang datang. Sedangkan, "pendidikan dalam pengertian yang luas adalah meliputi perbuatan atau semua usaha generasi tua untuk mengalihkan [melimpahkan] pengetahuannya, pengalamannya, kecakapan serta keterampilannya kepada generasi muda, sebagai usaha untuk menyiapkan mereka agar dapat memenuhi fungsi hidupnya, baik jasmaniah maupun rohaniah [Zuhairin, 1985:2].

Para ahli Filsafat Pendidikan, menyatakan bahwa dalam merumuskan pengertian pendidikan sebenarnya sangat tergantung kepada pandangan terhadap manusia; hakikat, sifat-sifat atau karakteristik dan tujuan hidup manusia itu sendiri. Perumusan pendidikan bergantung kepada pandangan hidupnya, "apakah manusia dilihat sebagai kesatuan badan dan jasmani; badan, jiwa dan roh, atau jasmani dan rohani? Apakah manusia pada hakekatnya dianggap memiliki kemampuan bawaan [innate] yang menentukan perkembangannya dalam lingkungannya, atau lingkungannyalah yang menentukan [domain] dalam perkembangan manusia? Bagimanakah kedudukan individu dalam masyarakat? Apakah tujuan hidup manusia? Apakah manusia dianggap hanya hidup sekali di dunia ini, ataukah hidup lagi di hari kemudian [akhirat]? Demikian beberapa pertanyaan filosofis" yang diajukan.

Pertanyaan-pertanyaan tersebut di atas, memerlukan jawaban yang menentukan pandangan terhadap hakekat dan tujuan pendidikan, dan dari sini juga sebagai pangkal perbedaan rumusan pendidikan atau timbulnya aliran-aliran pendidikan seperti; pendidikan Islam, Kristen, Liberal, progresif atau pragmatis, komunis, demokratis, dan lain-lain. Dengan demikian, terdapat keaneka ragaman pendangan tentang pendidikan. Tetapi, "dalam keanekaragaman pandangan tentang pendidikan terdapat titik-titik persamaan tentang pengertian pendidikan, yaitu pendidikan dilihat sebagai suatu proses; karena dengan proses itu seseorang [dewasa] secara sengaja mengarahkan pertumbuhan atau perkembangan seseorang [yang belum dewasa]. Proses adalah kegiatan mengarahkan perkembangan seseorang sesuai dengan nilai-nilai yang merupakan jawaban atas pertanyaan-pertanyaan tersebut di atas. Maka, dengan pengertian atau definisi itu, kegiatan atau proses pendidikan hanya berlaku pada manusia tidak pada hewan" [Anwar Jasin, 1985:2]. 
Dari uraian di atas, timbul pertanyaan apakah Pendidikan Islam itu? Pendidikan Islam adalah suatu pendidikan yang melatih perasaan murid-murid dengan cara begitu rupa sehingga dalam sikap hidup, tindakan, keputusan, dan pendekatan mereka terhadap segala jenis pengetahuan, mereka dipengaruhi sekali oleh nilai spritual dan sangat sadar akan nilai etis Islam [Syed Sajjad Husain dan Syed Ali Ashraf, 1986:2], atau menurut Abdurrahman an-Nahlawi, "pendidikan Islam mengantarkan manusia pada perilaku dan perbuatan manusia yang berpedoman pada syariat Allah [Abdurrahman an-Nahlawi, 1995:26].

Dari pandangan ini, dapat dikatakan bahwa pendidikan Islam bukan sekedar "transper of knowledge" ataupun "transper of training", ....tetapi lebih merupakan suatu sistem yang ditata di atas pondasi "keimanan" dan "kesalehan", yaitu suatu sistem yang terkait secara langsung dengan Tuhan [Roihan Achwan, 1991:50]. Dengan demikian, dapat dikatakan pendidikan Islam suatu kegiatan yang mengarahkan dengan sengaja perkembangan seseorang sesuai atau sejalan dengan nilai-nilai Islam. Maka sosok pendidikan Islam dapat digambarkan sebagai suatu sistem yang membawa manusia kearah kebahagian dunia dan akhirat melalui ilmu dan ibadah. Karena pendidikan Islam membawa manusia untuk kebahagian dunia dan akhirat, maka yang harus diperhatikan adalah "nilai-nilai Islam tentang manusia; hakekat dan sifat-sifatnya, misi dan tujuan hidupnya di dunia ini dan akhirat nanti, hak dan kewajibannya sebagai individu dan anggota masyarakat. Semua ini dapat kita jumpai dalam al-Qur'an dan Hadits [Anwar Jasin, 1985:2].

Jadi, dapat dikatakan bahwa "konsepsi pendidikan model Islam, tidak hanya melihat pendidikan itu sebagai upaya "mencerdaskan" semata [pendidikan intelek, kecerdasan], melainkan sejalan dengan konsep Islam tentang manusia dan hakekat eksistensinya. ...Maka,...pendidikan Islam sebagai suatu pranata sosial, juga sangat terkait dengan pandangan Islam tentang hakekat keberadaan [eksistensi] manusia. Oleh karena itu, pendidikan Islam juga berupaya untuk menumbuhkan pemahaman dan kesadaran bahwa manusia itu sama di depan Allah dan perbedaanya adalah terletak pada kadar ketaqwaan masing-masing manusia, sebagai bentuk perbedaan secara kualitatif" [M.Rusli Karim, 1991:29-32].

Pendidikan berupaya untuk menumbuhkan pemahaman dan kesadaran pada manusia, maka sangat urgen sekali untuk memperhatikan konsep atau pandangan Islam tentang manusia sebagai makhluk yang diproses kearah kebahagian dunia dan akhirat, maka pandangan Islam tentang manusia antara lain: Pertama, konsep Islam tentang manusia, khsusunya anak, sebagai subyek didik, yaitu sesuai dengan Hadits Rasulullah, bahwa "anak manusia" dilahirkan dalam fitrah atau dengan "potensi" tertentu [Anwar Jasin, 1985:2]. Dalam al-Qur'an, dikatakan "tegakkan dirimu pada agama dengan tulus dan mantap, agama yang cocok dengan fitrah manusia yang digariskan oleh Allah. Tak ada perubahan pada ketetapan-Nya.....[ar-Rum : 30]. Dengan demikian, manusia pada mulanya dilahirkan dengan "membawa potensi" yang perlu dikembangkan dalam dan oleh lingkungannya. Pandangan ini, "berbeda dengan teori tabularasa yang menganggap anak menerima "secara pasif" pengaruh lingkungannya, sedangkan konsep fitrah mengandung "potensi bawaan" aktif [innate patentials, innate tendencies] yang telah di berikan kepada setiap manusia oleh Allah [Anwar Jasin, 1985:3]. Bahkan dalam al-Qur'an, sebenarnya sebelum manusia dilahirkan telah mengadakan "transaksi" atau "perjanjian" dengan Allah yaitu mengakui keesaan Tuhan, firman Allah surat al-A'raf : 172, "Ingatlah, ketika Tuhanmu mengeluarkan keturunan Adam dari sulbi mereka dan menyuruh agar mereka bersaksi atas diri sendiri; "Bukankah Aku Tuhanmu?" firman Allah. Mereka menjawab; "ya kami bersaksi" yang demikian agar kamu tidak berkata pada hari kiamat kelak, "kami tidak mengetahui hal ini" [Zaini Dahlan, 1998:304]. Apabila kita memperhatikan ayat ini, memberi gambaran bahwa setiap anak yang lahir telah membawa "potensi keimanan" terhadap Allah atau disebut dengan "tauhid". Sedangakan potensi bawaan yang lain misalnya potensi fisik dan intelegensi atau kecerdasan akal dengan segala kemungkinan dan keterbatasannya.

Selain itu, dalam al-Qur'an banyak dijumpai ayat-ayat yang menggambarkan sifat-sifat hakiki manusia yang mempunyai implikasi baik terhadap tujuan maupun cara pengarahan perkembangannya. 
Misalnya saja: tentang tanggung jawab, bahwa manusia diciptakan tidak sia-sia, tetapi juga potensi untuk bertanggung jawab atas perbuatannya dan sesuai dengan tingkat kemampuan daya pikul seseorang menurut kodrat atau fitrah-nya [pada al-Mu'minun:115 dan al-Baqrah:286]. Selain itu juga manusia pada hakekat dan menurut kejadiannya bersedia dan sanggup memikul amanah [pada al-Ahzab : 72]. Di samping itu, hal yang juga penting implikasinya bagi pendidikan adalah tanggung jawab yang ada pada manusia bersifat pribadi, artinya tidaklah seseorang dapat memikul beban orang lain, beban itu dipikul sendiri tanpa melibatkan orang lain [pada Faathir:18]. Sifat lain yang ada pada manusia adalah manusia diberi oleh Allah kemampuan al-bayan [fasih perkataan - kesadaran nurani] yaitu daya untuk menyampaikan pikiran dan perasaannya melalui kemampuan berkomunikasi dengan bahasa yang baik [pada ar-Rahman:3-4]. Pada hadits Rasulullah, "barang siapa ingin mencapai kebahagian dunia harus ditempuh dengan ilmu dan barang siapa yang mencari kebahagian akhirat juga harus dengan ilmu, dan barang untuk mencari keduanya juga harus dengan ilmu". Dari pandangan ini, dapat dikatakan bahwa tugas dan fungsi pendidikan adalah mengarhkan dengan sengaja segala potensi yang ada pada seseorang seoptimal mungkin sehingga ia berkembang menjadi seorang muslim yang baik. Kedua, peranan pendidikan atau pengarah perkembanagan. Potensi manusia yang dibawah sejak dari lahir itu bukan hanya bisa dikembangkan dalam lingkungan tetapi juga hanya bisa berkembang secara terarah bila dengan bantuan orang lain atau pendidik. Dengan demikian, tugas pendidik mengarahkan segala potensi subyek didik seoptimal mungkin agar ia dapat memikul amanah dan tanggung jawabnya baik sebagai individu maupun sebagai anggota masyarakat, sesuai dengan profil manusia Muslim yang baik. Ketiga, profil manusia Muslim. Profil dasar seorang Muslim yang baik adalah ketaqwaan kepada Allah. Dengan demikian, perkembangan anak haruslah secara sengaja diarahkan kepada pembentukan ketaqwaan. Keempat, metodologi pendidikan. Metodologi diartikan sebagai prinsip-prinsip yang mendasari kegiatan mengarahkan perkembangan seseorang, khususnya pada proses belajar-mengajar. Maka, pandangan bahwa seseorang dilahirkan dengan potensi bawaan tertentu dan dengan itu ia mampu berkembang secara aktif dalam lingkungannya, mempunyai implikasi bahwa proses belajarmengajar harus didasarkan pada prinsip belajar siswa aktif [student active learning] [Anwar Jasin, 1985:4-5].

Jadi, dari pandangan di atas, pendidikan menurut Islam didasarkan pada asumsi bahwa manusia dilahirkan dalam keadaan fitrah yaitu dengan membawa "potensi bawaan" seperti potensi "keimanan", potensi untuk memikul amanah dan tanggung jawab, potensi kecerdasan, potensi fisik. Karena dengan potensi ini, manusia mampu berkembang secara aktif dan interaktif dengan lingkungannya dan dengan bantuan orang lain atau pendidik secara sengaja agar menjadi manusia muslim yang mampu menjadi khalifah dan mengabdi kepada Allah.

Bersarkan uraian di atas, pengertian pendidikan menurut al-Qur'an dan hadits sangat luas, meliputi pengembangan semua potensi bawaan manusia yang merupakan rahmat Allah. Potensi-potensi itu harus dikembangkan menjadi kenyataan berupa keimanan dan akhlak serta kemampuan beramal dengan menguasai ilmu [dunia - akhirat] dan keterampilan atau keahlian tertentu sehingga mampu memikul amanat dan tanggung jawab sebagai seorang khalifat dan muslim yang bertaqwa. Tetapi pada realitasnya pendidikan Islam, sebagaimana yang lazim dikenal di Indonesia ini, memiliki pengertian yang agak sempit, yaitu program pendidikan Islam lebih banyak menyempit ke-pelajaran fiqh ibadah terutama, dan selama ini tidak pernah dipersoalkan apakah isi program pendidikan pada lembagalembaga pendidikan telah sesuai benar dengan luasnya pengertian pendidikan menurut al-Qur'an dan hadits [ajaran Islam]

\section{PEMBAHARUAN PENDIDIKAN ISLAM}


Pendidikan Islam di Indonesia masih menghadapi berbagai masalah dalam berbagai aspek. Upaya perbaikannya belum dilakukan secara mendasar, sehingga terkesan seadanya saja. Selama ini, upaya pembaharuan pendidikan Islam secara mendasar, selalu dihambat oleh berbagai masalah mulai dari persoalan dana sampai tenaga ahli. Padahal pendidikan Islam dewasa ini, dari segi apa saja terlihat goyah terutama karena orientasi yang semakin tidak jelas [Muslih Usa, 1991:11-13]. Berdasarkan uraian ini, ada dua alasan pokok mengapa konsep pembaharuan pendidikan Islam di Indonesia untuk menuju masyarakat madani sangat mendesak. [a] konsep dan praktek pendidikan Islam dirasakan terlalu sempit, artinya terlalu menekankan pada kepentingan akhirat, sedangkan ajaran Islam menekankan pada keseimbangan antara kepentingan dunia dan akhirat. Maka perlu pemikiran kembali konsep pendidikan Islam yang betul-betul didasarkan pada asumsi dasar tentang manusia yang akan diproses menuju masyarakat madani. [b] lembaga-lembaga pendidikan Islam yang dimiliki sekarang ini, belum atau kurang mampu memenuhi kebutuhan umat Islam dalam menghadapi tantangan dunia modern dan tantangan masyarakat dan bangsa Indonesia disegala bidang. Maka, untuk menghadapi dan menuju masyarakat madani diperlukan konsep pendidikan Islam serta peran sertanya secara mendasar dalam memberdayakan umat Islam,

Suatu usaha pembaharuan pendidikan hanya bisa terarah dengan mantap apabila didasarkan pada konsep dasar filsafat dan teori pendidikan yang mantap. Filsafat pendidikan yang mantap hanya dapat dikembangkan di atas dasar asumsi-asumsi dasar yang kokoh dan jelas tentang manusia [hakekat] kejadiannya, potensi-potensi bawaannya, tujuan hidup dan misinya di dunia ini baik sebagi individu maupun sebagai anggota masyarakat, hubungan dengan lingkungan dan alam semesta dan akhiratnya hubungan dengan Maha Pencipta. Teori pendidikan yang mantap hanya dapat dikembangkan atas dasar pertemuan antara penerapan atau pendekatan filsafat dan pendekatan emperis [Anwar Jasin, 1985:8], Sehubungan dengan itu, konsep dasar pembaharuan pendidikan Islam adalah perumusan konsep filsafat dan teoritis pendidikan yang didasarkan pada asumsi-asumsi dasar tentang manusia dan hubungannya dengan lingkungan dan menurut ajaran Islam.

Maka, dalam usaha pembaharuan pendidikan Islam perlu dirumuskan secara jelas implikasi ayatayat al-Qur'an dan hadits yang menyangkut dengan "fitrah" atau potensi bawaan, misi dan tujuan hidup manusia. Karena rumusan tersebut akan menjadi konsep dasar filsafat pendidikan Islam. Untuk itu, filsafat atau segala asumsi dasar pendidikan Islam hanya dapat diterapkan secara baik jikalau kondisikondisi lingkungan ( sosial - kultural ) diperhatikan. Jadi, apabila kita ingin mengadakan perubahan pendidikan Islam maka langkah awal yang harus dilakukan adalah merumuskan konsep dasar filosofis pendidikan yang sesuai dengan ajaran Islam, mengembangkan secara empris prinsip-prinsip yang mendasari keterlaksanaannya dalam konteks lingkungan [sosial - cultural] yang dalam hal ini adalah masyarakat madani. Jadi, tanpa kerangka dasar filosofis dan teoritis yang kuta, maka perubahan pendidikan Islam tidak punya pondasi yang kuat dan juga tidak mempunyai arah yang pasti [Rangkuman dari Anwar Jasin, 1985:8 -9].

Konsep dasar filsafat dan teoritis pendidikan Islam, harus ditempatkan dalam konteks supra sistem masyarakat madani di mana pendidikan itu akan diterapkan. Apabila terlepas dari konteks "masyarakat madani", maka pendidikan menjadi tidak relevan dengan kebutuhan umat Islam pada kondisi masyarakat tersebut [masyarakat madani]. Jadi, kebutuhan umat yang amat mendesak sekarang ini adalah mewujudkan dan meningkatan kualitas manusia Muslim menuju masyarakat madani. Untuk itu umat Islam di Indonesia dipersiapkan dan harus dibebaskan dari ketidaktahuannya [ignorance] akan kedudukan dan peranannya dalam kehidupan "masyarakat madani" dalam konteks kehidupan berbangsa dan bernegara. Pendidikan Islam haruslah dapat meningkatkan mutu umatnya dalam menuju "masyarakat madani". Kalau tidak umat Islam akan ketinggalan dalam kehidupan "masyarakat madani" yaitu masyarakat ideal yang dicita-citakan bangsa ini. Maka tantangan utama yang dihadapi umat Islam sekarang adalah peningkatan mutu sumber insaninya dalam menempatkan diri dan memainkan perannya dalam komunitas masyarakat madani dengan menguasai ilmu dan teknologi yang berkembang 
semakin pesat. Karena, hanya mereka yang menguasai ilmu dan teknologi modern dapat mengolah kekayaan alam yang telah diciptakan Allah untuk manusia dan diamanatkan-Nya kepada manusia sebagai khalifah dimuka bumi ini untuk diolah bagi kesejahteraan umat manusia.

Maka masyarakat madani yang diprediski memiliki ciri ; Universalitas, Supermasi, Keabadian, Pemerataan kekuatan, Kebaikan dari dan untuk bersama, Meraih kebajikan umum, Perimbangan kebijakan umum, Piranti eksternal, Bukan berinteraksi pada keuntungan, dan Kesempatan yang sama dan merata kepada setiap warganya. Atas dasar konsep ini, maka konsep filsafat dan teoritis pendidikan Islam dikembangkan sebagai prinsip-prinsip yang mendasari keterlaksanaannya dalam kontek lingkungan masyarakat madani tersebut, sehingga pendidikan relevan dengan kondisi dan ciri sosial kultural masyarakat tersebut. Maka, untuk mengantisipasi perubahan menuju "masyarakat madani", pendidikan Islam harus didisain untuk menjawab perubahan tersebut. Oleh karena itu, usulan perubahan sebagai berikut : [a] pendidikan harus menuju pada integritas antara ilmu agama dan ilmu umum untuk tidak melahirkan jurang pemisah antara ilmu agama dan ilmu bukan agama, karena, dalam pandangan seorang muslim, ilmu pengetahuan adalah satu yaitu yang berasal dari Allah SWT, [b] pendidikan menuju tercapainya sikap dan perilaku "toleransi", lapang dada dalam berbagai hal dan bidang, terutama toleran dalam perbedaan pendapat dan penafsiran ajaran Islam, tanpa melepaskan pendapat atau prinsipnya yang diyakini, (c) pendidikan yang mampu menumbuhkan kemampuan untuk berswadaya dan mandiri dalam kehidupan, [d] pendidikan yang menumbuhkan ethos kerja, mempunyai aspirasi pada kerja, disiplin dan jujur [Suroyo, 1991:45-48], (e) pendidikan Islam harus didisain untuk mampu menjawab tantangan masyarakat madani.

Dalam konteks ini juga perlu pemikiran kembali tujuan dan fungsi lembaga-lembaga pendidikan [Anwar Jasin, 1985:15] Islam yang ada. Memang diakui bahwa penyesuaian lembaga-lembaga pendidikan akhir-akhir ini cukup mengemberikan, artinya lembaga-lembaga pendidikan memenuhi keinginan untuk menjadikan lembaga-lembaga tersebut sebagai tempat untuk mempelajari ilmu umum dan ilmu agama serta keterampilan. Tetapi pada kenyataannya penyesuaian tersebut lebih merupakan peniruan dengan tambal sulam atau dengan kata lain mengadopsi model yang telah dilakukan oleh lembaga-lembaga pendidikan umum, artinya ada perasaan harga diri bahwa apa yang dapat dilakukan oleh lembaga-lembaga pendidikan umum dapat juga dilakukan oleh lembaga-lembaga pendidikan agama, sehingga akibatnya beban kurikulum yang terlalu banyak dan cukup berat dan bahkan terjadi tumpang tindih.

Lembaga-lembaga pendidikan Islam mengambil secara utuh semua kurikulum [non-agama] dari kurikulum sekolah umum, kemudian tetap mempertahankan sejumlah program pendidikan agama, sehingga banyak bahan pelajaran yang tidak dapat dicerna oleh peserta didik secara baik, sehingga produknya [hasilnya] serba setengah-tengah atau tanggung baik pada ilmu-ilmu umum maupun pada ilmu-ilmu agama. Untuk itu, lembaga-lembaga pendidikan Islam sebenarnya mulai memikirkan kembali disain program pendidikan untuk menuju masyarakat madani, dengan memperhatikan relevansinya dengan bentuk atau kondisi serta ciri masyarakat madani. Maka untuk menuju "masyarakat madani", lembaga-lembaga pendidikan Islam harus memilih satu di antara dua fungsi yaitu apakah mendisain model pendidikan umum Islami yang handal dan mampu bersaing secara kompotetif dengan lembaga pendidikan umum atau mengkhususkan pada disain pendidiank keagamaan yang handal dan mampu bersaing secara kompotetif, misalnya mempersiapkan ulama-ulama dan mujtahid-mujtahid yang berkaliber nasional dan dunia.

\section{PENUTUP}


Berdasarkan paparan di atas, dapat disimpulakn sebagai berikut : [1] Menyarakat madani merupakan suatu ujud masyarakat yang memiliki kemandirian aktivitas dengan ciri: universalitas, supermasi, keabadian, pemerataan kekuatan, kebaikan dari dan untuk bersama, meraih kebajikan umum, piranti eksternal, bukan berinteraksi pada keuntungan, dan kesempatan yang sama dan merata kepada setiap warganya. ciri masyarakat ini merupakan masyarakat yang ideal dalam kehidupan. Untuk Pemerintah pada era reformasi ini, akan mengarakan semua potensi bangsa berupa pendidikan, ekonomi, politik, hukum, sosial budaya, militer, kerah masyarakat madani yang dicita-citakan. [2] Konsep dasar pembaharuan pendidikan harus didasarkan pada asumsi-asumsi dasar tentang manusia meenurut aajaran Islam, filsafat dan teori pendidikan Islam yang dijabarkan dan dikembangkan berdasarkan asumsi-asumsi tentang manusia dan lingkungannya. Atau dengan kata lain pembaharuan pendidikan Islam adalah filsafat dan teori pendidikan Islam yang sesuai dengan ajaran Islam, dan untuk lingkungan ( sosial - kultural) yang dalam hal ini adalah masyarakat madani. (3) Konsep dasar pendidikan Islam supaya relevan dengan kepentingan umat Islam dan relevan dengan disain masyarakat madani. Maka penerapan konsep dasar filsafat dan teori pendidikan harus memperhatikan konteks supra sistem bagi kepentingan komunitas "masyarakat madani" yang dicita-citakan bangsa ini..

\section{DAFTAR PUSTAKA}

Abdurrahman an-Bahlawi, 1995. Ushulut Tarbiyah Islamiyah wa Asalibiha fi Baiti wal Madrasati wal Mujtama', Dar al-Fikr al-Mu'asyir, Beiru-Libanon, Cet. II, 1983., Terj., Shihabuddin, Pendidikan Islam di Rumah Sekolah dan Masyarakat, Gema Insani Press,

Ahmad D. Marimba, 1974, Pengantar Filsafat Pendidikan Islam, al-Ma'arif, Bandung, Cet.III,.

Anwar Jasin, 1985, Kerangka Dasar Pembaharuan Pendidikan Islam : Tinjauan Filosofis, Jakarta.

Fathiyah Hasan Sulaiman, 1986. Bahts fi 'L-Madzhab al-Tarbawy 'Inda 'L-Ghazaly, Maktabah Nadhlah, Mesir, 1964., Terj., Ahmad Hakim dan M.Imam Aziz, Konsep Pendidikan al-Ghazali, P3M, Jakarta, Cet. I,

H.A.R. Tilar, 1998, Beberapa Agenda Reformasi Pendidikan Nasional Dalam Perspektif Abad 21, Tera Indonesia, Magelang, Cet. I,.

Imam Barnadib, 1997, Filsafat Pendidikan Sistem \& Metode, Penerbit Andi, Yogyakarta, Cet. Kesembilan,.

Komaruddin Hidayat, 1998, Masyarakat Agama dan Agenda Penegakan Masyarakat Madani, Makalah "Seminar Nasional dan Temu Alumni, Program Pasca Sarjana Universitas Muhammadiyah Malang, Tanggal, 25-26 September.

Masykuri Abdillah, 1999, Islam dan Masyarakat Madani, Koran Harian Kompas, Sabtu, 27 Februari.

Mufid, 1998, Reformasi Hukum Menuju Masyarakat Madani, Makalah "Seminar Nasional dan Temu Alumni, Programa Pasca Sarjana Universitas Muhammadiyah Malang", Tanggal, 25-26 September.

Muslim Usa (editor)1991, Pendidikan Islam di Indonesia antara Cita dan Fakta, Tiara Wacana, Yogyakarta, Cet. I,

M.Rusli Karim, 1991, Pendidikan Islam Sebagai Upaya Pembebasan Manusia, dalam Buku Pendidikan Islam di Indonesia antara Citra dan Fakta, Editor : Muslih Usa, Tiara Wacana, Yogya, Cet.Pertama.

Roihan Achwan, 1991, Prinsip-prinsip Pendidikan Islam Versi Mursi, dlm. Jurnal Ilmu Pendidikan Islam, Volume 1, IAIN Sunan Kalijaga Yogyakarta.

Soroyo, 1991, Antisipasi Pendidikan Islam dan Perubahan Sosial Menjangkau Tahun 2000, dalam Buku : Pendidikan Islam di Indonesia antara Cita dan Fakta, Editor : Muslih Usa, Tiara Wacana, Yogya.

Syed Sajjad Husain dan Syed Ali Ashraf, 1986, Crisis Muslim Education., Terj. Rahmani Astuti, Krisis Pendidikan Islam, Risalah. 
Thoha Hamim, 1999, Islam dan Masyarakat Madani (1) Ham, Pluralisme, dan Toleransi Beragama, Koran Harian "Jawa Pos", Kamis Kliwon, Tanggal, 11 Maret.

Zuhairini, dkk, 1995, Filsafat Pendidikan Islam, Bumi Aksara, Jakarta, Cet. II,

\section{BIODATA PENULIS}

Jenuri adalah Dosen Program Studi S1 PGSD UPI Kampus Cibiru

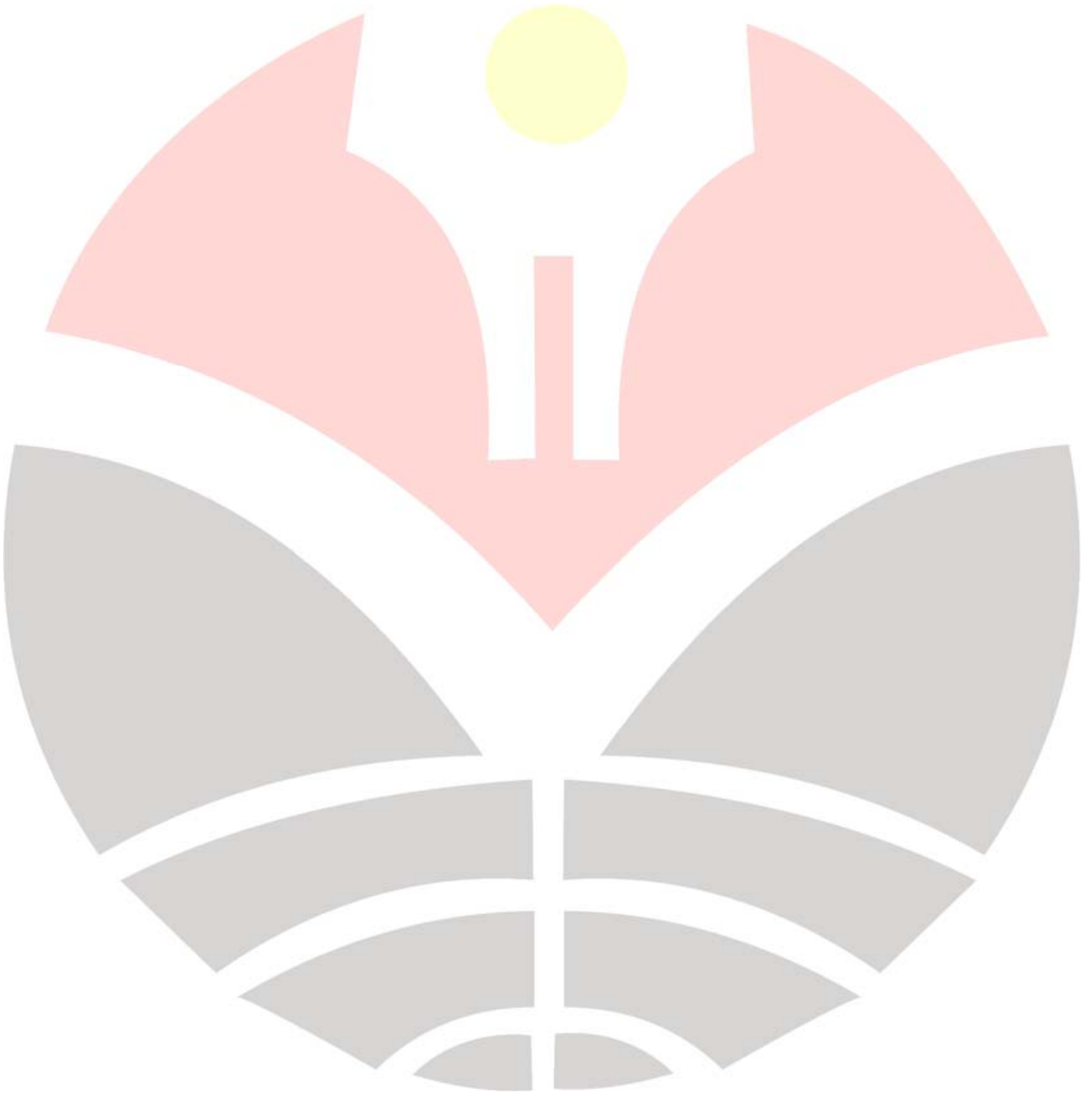

